Љиљана Марковић

Универзитет у Београду

Филолошки факултет $\quad$ 821.521.09-32

ljiljana.markovic@fil.bg.ac.rs https://doi.org/10.18485/ai_san_o_gradu.2018.ch5

\title{
ЈАПАНСКА ПРОЗА, ГРАД, КРОЗ УТОПИЈУ КА МОДЕРНИЗАЦИЈИ
}

Овај рад посматра елементе континуитета који повезују јапанско књижевно стваралаштво од периода Едо (1603-1868), преко периода Меиђи (1868-1912), па све до периода Таишо (1912-1926). Разматра се популарни писац свог времена Такизава Бакин (1767-1848), велики писац о Граду, о Еду, једном од највећих градова тог времена и његов књижевни утицај на касније писце јапанских утопијских дела. У периодима Едо и Таишо преведена су дела Дефоа, Мора, Свифта и Верна, што је утицало на настанак жанра мираики у јапанској прози периода Меиђи, са бројним политичким романима који говоре о савршеном друштву у будућем модерном Јапану. Утопија се тако везује за парадигму модернизације, док егзотичне локације идеалног друштвеног контекста замењује визија модернизованог и вестернизованог Јапана. Анализира се нит модернизацијске уйойије у делима Ућиде Роана и Нацуме Сосекија, као и њихови књижевни следбеници.

Кључне речи: град, Јапан, мираики, модернизација, утопија.

\section{Увод}

Друштвене околности које су утицале на формиње књижевних токова утопије везују се за историјске 
периоде и токове који су обликовали јапанску културну историју све од самог почетка 17. века, па до краја Другог светског рата. Фокусираћемо се на три периода јапанске историје: период Едо (1603-1868), познатији и као период Токугава, период Меиђи (1868-1912), период Таишо (1912-1926). Након периода Таишо наступа период Шова (1926-1989), међутим, с обзиром на дужину овог периода, културолошке аспекте ћемо анализирати тако што ћемо се фокусирати на период између периода Таишо до Другог светског рата, а затим на период након Другог светског рата.

Мираики књижевност (Суехиро 2013; Комине 2007) представља жанр који обухвата све наведене временске периоде, са зачетком у периоду Едо, јер он покрива тематику која се бави визијом о друштву у будућности, друштву које тек може развити, као плод идеје ствараоца који су овакав свет замишљали. Из тих разлога, имамо представнике у свим наведеним периодима, који су писали о оваквом Јапану.

\section{Стваралаштво периода Едо}

Период Едо је познат и као период самоизолације, када се строго контролише комуникација Јапана са Западом. Најдиректнија сарадња која је била успостављена са Јапаном је између Кине и Корејског полуострва, као и са холандским трговцима, преко луке Деђима, где је Холанђанима био дозвољен приступ.

Поред културе, трпео је и научни и технолошки напредак. Медицина се заснивала на старим кинеским списима, индустрија се није развијала, образовање није било доступно свима, упркос томе што је стопа образованог становништва расла.

Упркос наведеним факторима који су утицали на развој јапанског друштва у периоду Едо, може се истаћи 
да овај период карактерише појава штампе израђиване техником дрвотиска (средина 17. века), па се тако и мењају околности у којима се ствара књижевност. Ово утиче на промену књижевних токова и промена у виду тема које у овом периоду постају популарне. Књижевност постаје доступна обичном човеку и трговачкој класи. Такође, с обзиром да је ово период мира, ратничка класа полако почиње да тражи смисао свог постојања у образовању и окретању уметности, али и обичном народу. Носиоци књижевности пре овога периода, првенствено током периода Хеиан (794-1185), када је јапанска књижевност почела интензивније да се развија, углавном су били образовани људи високог сталежа у јапанском друштву (аристократија), па сходно томе теме којима су се они бавили - живот на двору - нису биле пријемчиве обичном човеку, иако са историјске тачке гледишта представљају ризницу извора података о тим периодима.

Радња романа у 17. веку смештена је у урбану средину, а тематика књижевности постављена је око људи трговачке класе и обичног човека. Смештање теме књижевности у овакво окружење доводи до промене тематике које су биле у жижи интересовања обичног човека. Свакодневни проблеми, градски живот, видови разоноде, друштвена окупљања и њихови описи (посебно карактеристично за околности стварања поезије) постају главна тематика књижевног стваралаштва. Представљена је такође и уметност онако како је види обичан човек. Хаику поезија, описи природе, квартова забаве у великим урбаним срединама и друго, само су неки од примера тема.

\section{Сликарство као облик уметности у Јапану}

Суми-е сликарство, иако се у Кини развило већ у 8. веку, а у Јапану се развија од 15 . века, посебан про- 
цват доживљава управо у овом периоду, када су познате слике самураја у комбинацији плавог или црног мастила на белој позадини.

Уметничка слика друштва које се развија ограничена је на јапанску културу и представља уметничку визију књижевника тог периода који су маштали о друштву које је коначно, након периода ратова, окренуто неким новим друштвеним вредностима и миру. Неоконфуцијанска и конфуцијанска мисао су главни филозофски стубови овога периода.

\section{Градови Јапана}

Формирање градских центара, првенствено Токија (тадашњег Еда), највише је допринело размени уметничке мисли и формирању плодног тла уметничког стваралаштва. Ослобођен културолошких стега малих места, Токио (Едо) представља симбол друштва које се мења, што је веома видно из обрађиване тематике која пре није била актуелна у књижевности пре овога периода. Поред Токија, битно је поменути и Кјото, који је био престоница Јапана пре него што је пресељена у Токио, Осаку, Нагоју итд. Иако по величини нису били као Токио, били су довољно развијени да остваре утицај на развој јапанске културе, пре него што се центар развоја преселио у Токио, односно Едо у 17. веку (Morishima 2001: 59).

Разматрајући неке од статистичких податка, можемо не само видети правац развијања јапанских градова, већ и угрубо упоредити са развојем градова на Западау. Тако, према Моришими (Morishima 2001: 75):

- Град Токио је, у последње две деценије периода Едо, био други милионски град у свету, после Лондона 
Јапанска проза, град, кроз утопију ка модернизацији 155

- Градови Осака и Кјото су имали 300 хиљада, односно 200 хиљада становника, док су Нагоја и Каназава имали по 100 хиљада становника

- Поред ових већих радова, урбане средине су биле успостављене и у местима Хирошима, Сендаи, Вакајама, Нагасаки, Кагошима, Сакаи

- Поређења ради, како Моришима наводи, према Марксу, 1850 године, у Енглеској, сем Лондона, није постојао ниједан град чија је популација прелазила 100 хиљада становника

- У Јапану је 1918. године било само 5 универзитета и 104 средње школе и колеџа, да би само деценију касније тај број порастао на 40 универзитета односно 184 средње школе и колеџа, а до краја 1945 било је 48 универзитета и 342 колеџа и средњих школа.

- Чак и данас, највећи универзитети у свом склопу имају вишу и нижу средњу школу, а неретко и основну.

Такизава Бакин ${ }^{1}$ (1767-1848)

Рођен је у Еду 1765. као пето мушко дете у породици у којој је отац био службеник самурајске куће (Тa-

1 Познат је и по имену Кјокуте Бакин (Kyokutei Bakin, 曲亭 馬 琴). Овај псеудоним је настао као игра речи проистекле из различитих начина да се идеограми којима се пише Бакиново име прочитају. Оваква тенденција, због природе јапанског писма, иначе није ретка у јапанском уметничком стваралаштву, било да је реч о књижевности или сликарству употпуњеним калиграфским записима. Идеограми имају своје читање и значење. Због ове карактеристике, у примерима сликовне уметности, идеограми са собом могу носити неко пренесено значење, или могу имати неку посебну вредност за уметника који их исписује неким од калиграфских стилова и као такви, ти калиграфски записи сами представљају уметничко дело са поруком коју уметник жели да пренесе. 
каги: 2004). Пошто није било ратова, самураји су постали део бирократије. Они су имали веома велики број службеника, а један од њих је био и отац Кјокутеи Бакина. Отац је волео хаикаи поезију и то је утицало и на његовог сина. Отац је умро у 51. години, Бакин је имао свега 10 година, а морао је да ради уместо оца. Одлучио је да напусти посао и да оде на пут. Старији брат и мајка су га наговарали да се запосли као самурај пешадинац, што је представљало најнижи самурајски ранг. Запослио се, али није могао да издржи у самурајској служби и у 18. години одлази на пут без одређеног циља. Није га држало место и увек је био жељан настави своја путовања. Када се вратио са пута, замолио је пријатеља и будућег књижевног ментора Сантоа (1761-1816) да му буде учитељ. Санто није хтео да га подучава, али му је дозволио да долази код њега и да сам учи. Тако почиње Бакинов књижевни рад. Касније ће он ослепети и његова снаја ће уствари записивати оно што је диктирао.

Бакин је писао помало необичне романе, ако се узме у обзир период његовог стваралаштва. У његовим делима присутан је висок степен имагинативности. Најважнији роман му је Нансо Сатоми Хаккенден („Легенда о осам паса породице Сатоми из Нансоа"). Писан је у наставцима а аутор је добијао од издавача упутства како да пише у зависности од реакција публике. На почетку романа, принцеза Фусехиме је затруднела. Родитељи су били љути јер није била удата. Она је желела да им докаже да није грешна и самој себи је распорила трбух. Тада се подигао бели дим и осам драгуља се распршило из њеног стомака (осам је срећан број јер се шири у бесконачност). Сваки је носио по један кинески знак који означава по једну врлину (вредноћу, искреност...). Касније се појављује осам дечака, од којих сваки носи по једну од ових особина. Сваки од њих је имао и по бе- 
лег који се разликовао по облику од осталих, али је сваки представљао латицу камелије. Ти дечаци су неком чудном судбином били повезани. Сваки дечак је у презимену носио идеограм који означава пса, нпр. „инумару“. Ових осам дечака су се нашли и одлучили да служе породици Сатоми. Били су храбри и одани самураји тој кући. Захваљујући њима, ова породица је добила тешку битку и успева да се брани од свег зла. Није се превише улазило у психу ликова.

\section{Период Меиђи (1868-1912)}

Након изласка из периода самоизолације и отварања ка Западу, под слоганом 和魂洋才 (wakon yōsai), јайански gyx, умеће Зайаga ${ }^{2}$, крећу промене јапанског друштва које су најверније осликане у књижевности ових периода. Слика Јапана, који је изашао из окова изолације и увидео колико заостаје за Западом, полако почиње да се мења и ставља у нови друштвени контекст. Носиоци модернизације овог периода је образована самурајска класа, која је такође била одговорна за званично покретање процеса рестаурације 1868. године.

Процес самоизолације није био нагло прекинут 1868. године. Већ од 1847. године (период Едо), јапанска војна владавина, схвативши колико је немоћна пред западним силама, полако попушта окове изолације и

2 Овај слоган се први пут појављује у модерном периоду јапанске културе, након Рестаурације Меиђи (1868). Реч yōsai са јапанског се може превести као: йаленай, умеђе, знане, етиос. На пример, Моришима (Morishima: 2001) већ у поднаслову своје монографије користи реч етиоc (Western Technology and the Japanese Ethos). Сматрамо да је свако решење прихватљиво, јер је термин тешко превести у буквалном значењу. Слоган означава сусрет јапанске воље за модернизацијом и знања које је дошло са Запада. 
дозвољава почетак преговора о, у тадашњем тренутку, могућем будућем процесу модернизације.

Већ у овом периоду, одваја се слој становништва који је веома заинтересован за „хватање корака са Западом“ - тренд који се наставља током периода Меиђи.

У периоду Меиђи, Руско-јапански рат (1904-5) је одиграо велику улогу у увођењу Јапана и јапанске културе на велика врата. Победа над тадашњом руском војском, која је била развијенија од јапанске, омогућила је да Јапан постане видљив на светској културолошкој мапи. Овде се може аргументовати да је овако почео не само утицај Запада на Јапан, већ и буђење интересовања Запада за јапанску културу, уметност, књижевно стваралаштво и др.

\section{Период Таишо (1912-1925)}

Модерно јапанско друштво, које је сустигло Запад у технолошком, друштвеном, културном и уметничком смислу полако постаје опсесија јапанске интелектуалне елите. Индустријализација, прихватање стилова облачења, моде и усвајање манира са Запада у свакодневном животу, само су неки од примера убрзаних друштвених промена кроз које је друштво у Јапану пролазило.

Ослањање на информације о култури Запада, иако можда штуре у том тренутку, није била неуобичајена пракса.

Већ у 18. веку, споро почиње да пробија западна мисао на тло Јапана, али те информације још увек нису доступне обичном човеку већ само појединим Јапанцима којима је било дозвољено или који су кришом отишли у неку од држава западне Европе да се образују (најчешће Француска, Немачка, Енглеска). 
Чак и у периодима Меиђи и Таишо, могло би се рећи да су, с обзиром да нису добро познавали западни свет, Јапанци у свом стваралаштву приказивали визију једне државе, народа, насеља, градова и култура, која је била у великој мери имагинарна: таква слика друштва није припадала ни Јапану, али ни било којој, постојећој у стварности, а Јапану у том тренутку недокучивој земљи.

Велики токијски земљотрес, 1923. године

Пратећи јапанску историју, уочљиво је колико су природне катастрофе играле улогу у историјским догађајима: тајфуни који су спречили две Монголске инвазије (1274. и 1281. године), громови од којих су горели и неки од најпознатијих храмова широм Јапана, али и велики Канто земљотрес 1923. године, названог Велики земљотрес.

Након Великог земљотреса, 1. септембра 1923. године, велики део регије Канто бива уништен, а самим тим и скоро пола површине Токија. Након овога, град се обнавља страховито великом брзином и само седам година након земљотреса Влада званично проглашава крај обнове Токија. Како је западна култура већ била присутна у Јапану, ово представља нову прекретницу у модерним трендовима Токија, који се касније шире на цео Јапан. Продавнице и кафићи по узору на западне, замењују чајџинице, и постају симбол модерног Јапана. Саграђени су у потпуности по западњачким узорима. Приликом уласка у продавнице више се не изува, роба је приступачна за куповину ширим друштвеним слојевима, а продавнице по први пут имају излоге. Тако се формира слој становништва који, иако није у могућности да много тога купи, почиње да обилази град и гледа излоге - пракса који није до тада није била позната 
у Јапану. Кафић представља место где се слушала џез музика, поред осталих жанрова, и где се први пут уводи пракса у друштву да се слободно време проводи на таквом месту, једноставно уживајући у музичкој уметности, или можда проводећи време на таквим местима док пишу роман и друго. Неретко су овакви кафићи били украшени понеком репликом слике са Запада. Овај вид уметности Запада је био посебно допадљив Јапанцима који се са таквом врстом музике до тада нису сусретали. Тенденција описа џез музике и џез барова се може срести и данас у модерној књижевности, посебно код веома популарног Харукија Муракамија. Културни центар се помера у Гинзу, која је и дан данас најпознатија пословна, трговачка и забавна четврт у Јапану. Први пут у јапанској историји се формира модерна урбана култура, која настаје из рушевина обновљеног Токија.

Такође, у делу града који је био уништен били су смештени центри скоро свих дешавања у то време. Трговински, пословни и културни. Прва ствар која се десила после земљотреса је сељење људи западно од делова града који су били разрушени. Поред Гинзе, један део послодаваца прелази да послује у област Маруноући, које је било знатно мање разрушено. Послодавци су у ове крајеве преселили и своје пословање, али и своје домове. Ова област је, заједно са Гинзом, и данас један од најужурбанијих делова Токија.

Пруге су грађене како би повезивале овај део града са осталим крајевима. Изграђивани су трговински центри, биоскопи, позоришта, кафићи и све остало што је било потребно за удобан живот људи. Ово је такође била прилика да се изграде модерне грађевине. Биоскопи су грађени по последњим стандардима, згаде и куће су биле све више у западњачком сти- 
лу, фабрике су грађене са постројењима која су била последња реч технологије у то време. Јапан је одувек био смештен у веома еруптивном подручју и увек су се трудили да се прилагођавају тим условима. Земљотрес у Токију их је подсетио на то, и грађевине које су градили су биле плански постављане да буду отпорније на земљотресе (али, рецимо, данашње зграде у Јапану које представљају пример једног од најсавременијег архитектонског планирања и које ће се одупрети и веома јаким земљотресима су почеле са градњом тек седамдесетих година прошлог века). Све што је у то време било грађено и обнављано у Јапану је тада било по последњим стандардима. Гинза полако преузима улогу водећег кварта и чак и данас представља симбол свега што је модерно у Јапану.

Ресторани су такође прављени у западњачком стилу, па се тако више није седело на поду, односно татамију, већ су постојале класичне столице са столовима. Жене су такође биле слободније и сада им је било дозвољено да једу у јавности.

Међутим, како је број млађе популације био велики, они нису били у могућности да купују било шта што би се налазило у излозима нових продавница, већ су само пролазили поред излога, па им је то убрзо постала рутина када би имали слободног времена.

\section{Културолошке промене периода Меиђи и Таишо}

Утопија је једна од кључних карактеристика Јапанске књижевности у периодима бурних и брзих корака јанског друштва и културе ка модернизацији по западњачком узору. Ако је „цивилизација“ бунмеи обележила период рестаурације Меиђи, онда се може рећи 
да је „култура“, или бунка обележила период од почетка раних двадесетих година двадесетог века, све до краја Другог светског рата. У овом периоду се могу видети најконкретније промене у друштву које је донела модернизација. Јапан постаје земља која све више личи на земље са Запада. Ово се може видети у промени стила облачења, популарних начина за одмор и кафићима.

У периоду од 1930. године, па све до краја Другог светског рата народ, интелектуалци, политичари и државници покушавају да пронађу себе и створе модеран Јапан који може да пркоси остатку света, али не и да заборави своје корене. Свет се налази у економској кризи, односно у рецесији, па ова ситуација није заобишла ни Јапан. Развој војне силе је још једна од карактеристика јапанског друштва у овом периоду. Овај период се можда може упоредити са конзерватизмом периода Меиђи, али постоје разлике. На почетку периода Меиђи су се супротставиле две струје неистомишљеника, они који су били за модернизацију и они који су били против ње. У овом периоду имамо сличну ситуацију, с тим што више није питање да ли ће се Јапан модернизовати, јер је већ био на том путу, већ како пронаћи онај пут који ће бити јединствен за Јапан, а не да буду чиста копија Јапана.

Јапанци су бег из проблема због тешких услова у којима су живели и свих проблема који су снашли државу тражили у забави и уживању, бар средња друштвена класа, која је највише испаштала због ове ситуације.

\section{Урбани симболи модернизације}

Кафићи, који представљају један од значајних симбола модерниазције и промена су били у потпуности у западном стилу - служећи храну и пиће са За- 
пада, и пуштајући џез и сличну музику. Ови кафићи, наиме, нису били новина у периоду после земљотреса Канто, када је настао највећи број њих, они су постојали већ од рестаурације Меиђи, али за разлику од тог периода, када су главне муштерије били уметници и интелектуалци, сада је овакве објекте углавном посећивала средња класа становништва (Morishima 2001: 51-57).

Кафићи су били такође и пример појаве потрошачког друштва и представљају све оно што је модерно. Кафићи представљају масовну културу у два смисла: први је чињеница да је кафић производ масовних медија и рекламирања, а друга је то што је експанзија кафића настала због све веће тражње Јапанаца за овим видом забаве. Кафићи представљају јако добар пример пада морала у друштву у овом периоду. У кафићима су се запошљавале младе девојке које су или остајале без посла у другим фирмама или им је једноставно више одговарало да раде на таквим местима. Оне су биле у обавези да на разне начине забаве оне муштерије које су долазиле у кафиће, али и да на најкреативније могуће начине привуку нове госте. Морале су да склапају пријатељства са њима, што би често прелазило друштвено прихватљиве границе тог периода. Оваквих места је било много и девојке су подстицане на што бољи рад како би могли да се изборе са конкуренцијом. Овакав начин живота су многи, наравно, критиковали, али су критике првенствено биле усмерене према томе да је то лоше јер је дошло са Запада. Они су сматрали да је Запад декадентан, а да је Јапан ишао тим стопама. Осудили су уживање као начин живота, објашњавајући како је сувише себично водити такав живот који би био практично без циљева, односно само са једним циљем - уживањем. Кафићи су представљали све оно 
што је лоше, али што се сматрало урбаним и модерним. Током двадесетих година двадесетог века девојке које су се запошљавале у кафићима су хапшене, а студентима је био забрањен приступ оваквим местима.

\section{Писци са утопијском тематиком који су обележили јапанску књижевну мисао}

\section{Нацуме Сосеки (1867-1916)}

Нацуме Сосеки (Кеene 2003) један је од најзначајнијих писаца који је обележио како књижевно стваралаштво периода Меиђи тако и периода Таишо. У свом делу Кокоро (1914), он приказује разлику између живота у граду и на селу. Младић који одлази на студије описује разлику две културе: једну у којој је одрастао и којој припадају његови родитељи, односно руралне средине, и другу, која за њега представља нови живот, односно велики град и живот и све оно што са њиме долази. Упечатљива су његова поређења начина размишљања ова два света, кроз анализе самог протагонисте коме је свет у који се враћа из великог града, иако је то свет у коме је одрастао, потпуно стран са културолошке тачке гледишта.

\section{Ућида Роан (1868-1929)}

Ућида Роан (Иваи 1997: 49) књижевник је који је можда највише био под утицајем западне књижевност. Напушта високу специјалистичку школу (која касније постаје Универзитет Васеда), након чега се посвећује пословима грубих превода краћих текстова као помоћ ујаку који је радио у Министарству просвете. Усавршава своје знање страних језика и даље се интересује за страну књижевност и превођење. Године 1895. преводи на јапански Злочин и казну, што представља његов 
највећи преводилачки допринос. Ово је уједно и прво дело које је прочитао из корпуса Западне књижевности, а оставило је оставило веома јак утисак на њега, након чега наставља да се бави књижевношћу са 3апада. Преводио је и Андерсена, Дикенсена, Диму, Золу и друге писце. Овиме је успео да приближи западну мисао јапанској култури и створи основ за књижевно стваралаштво осталих писаца овог периода.

\section{Период након Другог светског рата}

Утопијски ствараоци овог периода изложени су веома великој друштвеној динамици. У жељи да представе друштво што верније морали су да разреше дилеме које су биле присутне у тадашњем Јапану. Непосредно пре почетка Другог светског рата, Јапан прекида све интелектуалне контакте са Западом и окреће се стваралаштву обојеном националистичким нотама. Ово је књижевни одраз драстичних промена у политици и образовању. С обзиром да Јапан излази као губитник на крају Другог светског рата, Јапанци у овом периоду нису у могућности да слободно диктирају нове друштвене трендове. Писци овог периода су у дилеми: да ли се окренути новим трендовима у стваралаштву и култури Запада, или поштовати раније, предратне друштвене конвенције. Ова дилема је решена увођењем друштвено прихватљивог облика демократије према стандардима јапанске мисли и културним нормама. Ствараоци бирају да описују модерно друштво које обликује демократија. Поређењем стваралаштва након Другог светског рата са стваралаштвом периода Меиђи, примећујемо да су текстови са утопијском тематиком далеко мање допадљиви читаоцима. Разлог се може пронаћи у веома једноставној чињеници - Јапан 
је изашао као губитник, а разореном Јапану није било лако пронаћи мотивацију за утопијско стваралаштво.

Књижевници се окрећу научнофантастичним темама које су под директним утицајем књижевности Запада. Стога се већ може на неки начин говорити о крају класичне утопијске књижевности у Јапану. Без обзира на то, у модерној јапанској књижевности постоји неколико писаца који су вредни пажње управо због свог покушаја да представе модерно друштво са универзалне тачке гледишта, а кроз тематику дела исказују своја предвиђања о развоју друштва, као и критику модерних друштвених тенденција.

Тако Јукио Мишима (Keene 2003), у свом делу Прелейа звезgа (Utsukushii hoshi 1962), представља човека као ванземаљца који је послат да истражи Месец, а под снажним утицајем краја Другог светског рата и бацања атомских бомби, тематика се проширује и на глобално уништење. Ова тематика нам је јасна из представљеног незадовољства протагонисте приповетке, Оцугија, који се пита да ли је човечанство уопште вредно очувања. Сматра се да се кроз ово негодовање осликава Мишимино незадовољство друштвеним променама и даљем позападњачавању јапанског друштва. Иако јединствена, приповетка није доживела успех јер је продата у само 20 хиљада примерака, што показује да Јапанци нису били отворени за теме које нису приказивале реалистичне слике друштва.

Кензабуро Ое (1935-), други јапански Нобеловац (1994), такође се бави представљањем јапанског друштва, али кроз мотиве прихватања различитости. Пише дело Chiryōto (Паїоga озgрављень 1991), у којој је представљен човек са савршеним телом, излеченим од сваке овоземаљске болести. Овиме алудира на проблем болести које харају светом и од којих умире највећи 
број становника широм планете. Тематика у којој је главни лик стављен у средину у којој се не уклапа по друштвеним стандардима с почетка, али успева да се прилагоди, није страна многим Оевим делима. Као и Мишимина приповетка, ни ова прича није доживела велику популарност у поређењу са осталим његовим делима. И данас остаје један од највећих критичара чињенице да јапанско друштво веома тешко прихвата све оно што одступа од усвојених друштвених конвенција, било да је у питању особа са здравственим проблемима или особа другачије културолошке позадине од јапанске.

Трећи представник је Кобо Абе (1924-1993) (Keene 2003) чије је стваралаштво достигло чак и већу популарност од Мишиминог и Оевог. Он представља своју визију друштва у будућности кроз научнофантастични детективски роман (Унуйарне леgено gоба $\delta р$. $4,1959)$, у коме развија теорију о компјутерима који ће бити способни да прикажу будућност. На крају, у причи он представља човека који је у будућности способан да живи под водом, али има жељу да изађе на копно и истражи „древног човека“. Поигравање са природним феноменима не би ли се приказале друштвене законитости је једна од главних одлика Абеових дела (нпр. Жена у йеску, 1964).

Закључак

Утопија је једна од кључних карактеристика јапанске књижевности у периодима бурних и брзих корака јанског друштва и културе ка модернизацији по западњачком узору. Промене које су окарактерисале овај период осликане су у књижевности, верно приказујући борбу за потрагом идеалног у јапанској модерној култури. 


\section{Библиографија}

Duus, Peter. The Cambridge history of Japan, The Twentieth Century, Volume 6. Cambridge: Cambridge Uversity Press, 1988.

Horio, Teruhisa, Steven Platzer (Ed). Educational Thought and Ideology in Modern Japan: State Authority and Intellectual Freedom. Tokyo: University of Tokyo Press, 2001.

Morishima, Michio. Why has Japan 'succeeded'? Western Technology and the Japanese Ethos. UK: Cambridge University Press, 2001.

Mostow, Joshua ed. The Columbia Companion to East Asian Literature. New York: Columbia University Press, 2003.

Rimer, Thomas J. The Reader's Guide to Japanese Literature. Tokyo: Kodansha International, 1991.

Keene, Donald. Five Japanese Modern Novelists. NewYork: Columbia University Press, 2003.

Mostow, Joshua ed. The Columbia Companion to East Asian Literature. New York: Columbia University Press, 2003.

Rimer, Thomas J. The Reader's Guide to Japanese Literature. Tokyo: Kodansha International, 1991.

Иваи (1997): 岩井寛『作家の臨終 墓碑事典』（東京堂出 版、1997年）49頁

Суехиро (2013): 二十三年未来記 (リプリント日本近代文学) 末広 鉄腸 (平凡社、2013年)

Комине (2007): 中世日本の予言書一“未来記”を読む (岩波 新書, 2007) 新書

Интернет странице (есејски чланци):

Такаги (2004) : 曲亭馬琴 (千葉大学文学部 高木元) : http:// www.fumikura.net/other/bakin.html. Последњи приступ: 22. јун 2018. године 
Prof. Ljiljana Marković, PhD

\section{JAPANESE PROSE - CITY, THROUGH THE UTOPIA TO MODERNIZATION}

\section{Summary}

This work looks at the elements of continuity that connect Japanese literary creativity from the period of Edo (1603-1868), through the period of Meiji (1868-1912), to the period of Taisho (1912-1925). The popular writer Takizava Bakin (1767-1848) the great writer about the city, is considering, about Ed, one of the greatest cities of that time, as well as his literary influence on the later writers of Japanese utopian writings. In the periods of Edo and Taisho, the works of Defo, Mor, Svift and Vern were translated, which influenced the emergence of a genre miraick $i$ in the Japanese prose of the period of Meiji, with numerous political novels that speak of the perfect society in the future modern Japan. Utopia thus binds to the paradigm of modernization, while the exotic locations of the ideal social context are replaced the vision of modernized and westernized Japan. The thread of the modernization utopia is analyzed in the works of the Udida Roan and Nacum Sosekij, as well as their literary followers.

Key words: utopia, city, modernization, Japan, miraicki. 